\title{
Toward universal electrification in Ghana
}

\author{
Kemausuor, Francis; Ackom, Emmanuel
}

Published in:

Wiley Interdisciplinary Reviews: Energy and Environment

Link to article, DOI:

10.1002/wene.225

Publication date:

2017

Document Version

Peer reviewed version

Link back to DTU Orbit

Citation (APA):

Kemausuor, F., \& Ackom, E. (2017). Toward universal electrification in Ghana. Wiley Interdisciplinary Reviews: Energy and Environment, 6(1), [e225]. https://doi.org/10.1002/wene.225

\section{General rights}

Copyright and moral rights for the publications made accessible in the public portal are retained by the authors and/or other copyright owners and it is a condition of accessing publications that users recognise and abide by the legal requirements associated with these rights.

- Users may download and print one copy of any publication from the public portal for the purpose of private study or research.

- You may not further distribute the material or use it for any profit-making activity or commercial gain

- You may freely distribute the URL identifying the publication in the public portal

If you believe that this document breaches copyright please contact us providing details, and we will remove access to the work immediately and investigate your claim. 


\title{
(WILEY \\ Interdisciplinary \\ Reviews \\ ENERGY AND ENVIRONMENT
}

Please select the appropriate article type (per your Contributor's Agreement) by double-clicking on the associated check box.

\begin{tabular}{|l|l|l|l|}
\hline$\square$ & Overview & $\begin{array}{l}\text { Overviews will provide a broad and relatively non-technical treatment of } \\
\text { important topics at a level suitable for advanced students and for } \\
\text { researchers without a strong background in the field. }\end{array}$ & $\begin{array}{l}4,000-5,000 \text { words } \\
10-15 \text { figures/tables } \\
50-55 \text { references }\end{array}$ \\
\hline$\square$ & $\begin{array}{l}\text { Advanced } \\
\text { Review }\end{array}$ & $\begin{array}{l}\text { Advanced Reviews, aimed at researchers and advanced students with a } \\
\text { strong background in the subject, will review key areas of research in a } \\
\text { citation-rich format similar to that of leading review journals. }\end{array}$ & $\begin{array}{l}7,000-9,000 \text { words } \\
20-25 \text { figures/tables } \\
100-110 \text { references }\end{array}$ \\
\hline$\square$ & Focus Article & $\begin{array}{l}\text { Focus articles are short articles, sometimes included within a larger article, } \\
\text { that describe specific real-world issues, examples, implementations, etc. } \\
\text { These articles will be technical in nature. }\end{array}$ & $\begin{array}{l}3,500-4,500 \text { words } \\
3-5 \text { figures/tables } \\
15-25 \text { references }\end{array}$ \\
\hline$\square$ & Opinion & $\begin{array}{l}\text { Opinions provide a forum for thought-leaders, hand-picked by the editors, } \\
\text { to provide a more individual perspective on the field in question. }\end{array}$ & $\begin{array}{l}3,000-4,000 \text { words } \\
6-10 \text { figures/tables } \\
15-25 \text { references }\end{array}$ \\
\hline$\square$ & $\begin{array}{l}\text { Editorial } \\
\text { commentaries } \\
\text { areas of research in a flexible and informal style; they are broadly } \\
\text { comparable to journal-style 'editorials'. We would expect to see an } \\
\text { Editorial commentary from the Editor in Chief in the launch issue of the } \\
\text { WIRE, and occasional contributions (no more than one per issue on } \\
\text { average) thereafter. }\end{array}$ & \\
\hline
\end{tabular}

\section{Towards universal electrification in Ghana}

\author{
First author: Full name and affiliation; plus email address if corresponding author \\ Francis Kemausuor; Kwame Nkrumah University of Science and Technology, Kumasi, \\ Ghana; fkemausuor.soe@knust.edu.gh \\ Second author: Full name and affiliation; plus email address if corresponding author \\ *Emmanuel Ackom; UNEP DTU Partnership, Technical University of Denmark (DTU), \\ Copenhagen, Denmark; emac@dtu.dk
}

\section{Abstract}

With the exception of a few countries in sub-Saharan Africa, Ghana's electrification access trend has been lauded as shining example in the region. A roadmap set in motion in 1989 appears to be inching closer to its target of universal access by 2020 , with the national grid extended to more than $70 \%$ of the population in the country. Notwithstanding this feat, a number of challenges remain. 
Load shedding / power rationing has become the bane of the power sector in Ghana, sometimes equating to about 24 hours of power cuts in every 36 hours for some communities. This has been partly blamed for the economic woe the country is currently experiencing. The load shedding has been as a result of low generation capacity, which itself has arisen from poor planning and the lack of attention to a growing economy and population, which has increased demand for power. In addition, fuel supply to the existing thermal power plants has been an uphill task, meaning that installed capacity is often not available for use. In addition to increasing electricity generation capacity, Ghana would have to also explore alternative ways of obtaining fuel, such as regasification, to solve the chronic issue of natural gas shortage. An increased generation level is likely to expose weaknesses in the transmissions grid, which is operating at a perilously unsafe capacity. Ghana could take advantage of provisions within the West Africa power Pool to explore inter-regional connectivity that could boost the stability of its transmissions grid.

\section{BACKGROUND}

To some people, access to electricity should be a basic right. ${ }^{1,2}$ In most of sub-Saharan Africa (SSA) and South East Asia, this may be a fallacy, at least not for the present. There are little to no questions to the generally accepted fact that access to energy is indispensable to economic development. ${ }^{3,4,5}$ Indeed each dollar investment in energy supply potentially results in fifteen times more economic growth. ${ }^{4}$ Energy consumption enhances productivity, economic growth and global networking. ${ }^{6,7,8,9,10,11}$ This notwithstanding, nearly 1.3 billion people on the globe are without access to electricity ${ }^{4}$. The situation is worse in South East Asia and sub-Saharan Africa, where access to electricity is among the lowest in the world. In sub-Saharan Africa (SSA), only 30-33\% of the population have access to electricity. ${ }^{4,12}$ South Africa appears to be in a different class, notwithstanding its higher population, with more than $80 \%$ of its population having access to electricity (see Figure 1). ${ }^{4,8}$ Other countries in SSA faring better with regards to electrification rates, though with lower population, are Mauritius (100\%), Reunion (99\%), Seychelles (97\%) and Gabon (89\%) (Figure 1). But even for a majority of the population that have access to electricity, unreliable power supply is a challenge that has bedevilled the region for several years. Many countries in SSA have severe power shortages. According to Refs 13 and 14, this is due to the fact that most countries have a monopolistic concept pertaining to their national energy supply, which results in deficient maintenance, poor procurement of spare parts, high transmission and distribution (T\&D) losses, constant power failure resulting from faults at power stations, damage of power lines, short circuits, and low voltage. For example, losses in SSA have been reported to be among the highest in the world, with countries such as Congo and Togo reporting T\&D losses of 45 and $57 \%$ respectively, of their total generation capacity. ${ }^{4}$ 
Ghana, a country located on the west coast of Africa, finds itself saddled with these power shortage challenges, hampering an otherwise shining access rate to electricity. With the electricity grid covering more than $70 \%$ of the country as at 2013 , Ghana's access rate outshines that of her West African neighbours. The high electricity access rate is the result of a roadmap that began in 1989 with the establishment of a National Electrification Scheme (NES). Under the NES, the country laid out its plan to extend electricity access to cover the entire country by 2020. The ambitious goal of the NES was to provide within a 30-year time frame, electricity access to all settlements which had an adult population greater than 500 . The impressive impacts of the NES were evident in the electrification of 2,350 communities within ten years after the launch, about $56 \%$ of the original 4,200 targeted communities. ${ }^{15}$ The Scheme which seemed over-ambitious at the outset has been a significant driver of electricity access through discrete programmes such as the Self-Help Electrification Scheme (SHEP). Under the SHEP for instance, clearly stated significant contributions or commitments are expected from both the government and communities seeking to get connected to grid electricity. Households of non-electrified communities mobilize resources for the provision of low voltage poles and meters after at least $30 \%$ of households in the community have wired their households ready to receive power. Others make requests from their respective local governments for assistance usually in the form of providing low voltage poles and other electrification logistics. Given the burning desire to get their households connected to the grid with some form of assistance from the government, households of non-electrified communities have found it relatively cheaper to mobilize funds to complement the government's efforts for grid expansion compared to the period when the SHEP was non-existing. Successive governments have all strived to implement the plan towards attaining the goals of the NES and recent analysis shows that it is indeed possible to achieve this feat by 2020 for communities with adult population more than $500 .{ }^{16}$

But as noted by Ref 16 , access goes beyond having connection at home. Ensuring reliable supply of electricity is equally important. Unfortunately, unreliable power supply has been the bane of Ghana's power sector and that could lay waste to the idea of universal access. In the years 1983-4, 1997-98, 2003, 2006-2007, 2011-date, the country has suffered from severe power rationing / load shedding (or to use a more common local term in the country, 'dumsor'). When it first started in 1983-4, 1998 and then later on in 2003, power rationing was attributed to low water levels in the Akosombo hydro-electric dam, which was then contributing between 80 and $90 \%$ of the generation capacity. During the 2006/2007 electricity power rationing, equating to about 24 hours light in 48 hours, Ref 17 argued that the old reason of low water inflows was no longer tenable. Rather, it appeared to have been the result of poor planning coupled with a persistent disregard for the increasing trends in electricity demand, especially as the drought situation kept repeating. Demand had outpaced supply over the years with virtually no reserve margin for emergencies. Since 2011, power rationing has become a regular phenomenon in Ghana and is perhaps the most debated issue in the country today. All of a sudden, Ghanaians seem to be losing out on the one thing they have boasted of among their peers in West Africa: reliable power supply.

The current power rationing has affected all sectors of the Ghanaian economy, slowing down manufacturing and other industrial activities. ${ }^{18,19}$ The principal reason attributed to the latest rationing is low generation capacity, details of which are presented in later sections of this paper. Unreliable power supply is said to have cost the nation between $\$ 320$ million and $\$ 924$ million 
annually or $2-6 \%$ of Gross Domestic Product. ${ }^{11}$ It has also been indicated by Ref 20 that Ghana lost $1.8 \%$ of GDP during the 2007 electricity crisis. Again in 2014, the power crisis is said to have cost Ghana US\$ 680 million or $2 \%$ of GDP, with many businesses loosing sales of between 37 and $48 \%{ }^{21}$ It is estimated that companies spend $\$ 62$ million a month, or about $\$ 744$ million a year, on extra power generation, or about $6 \%$ of the country's entire economic output during severe power cuts. ${ }^{18}$ A study by Ref 22 found that close to $50 \%$ of micro and small scale industries in the country often spent several hours per month not working because of lack of reliable power while the rest relied on expensive alternative power from diesel generators that raised their cost of production. Several Ghanaians have, in the process, lost their jobs due to the energy crisis. Ref 23 reports that about a thousand workers were laid off between December 2014 and March 2015 due to poor power supply which resulted in low output. Tolerance for frequent power rationing has reached its lowest level in the country ${ }^{24}$ and urgent solutions are needed to curb a further deterioration.

But even in the midst of all these challenges, government is relentless in its aim for universal electrification by 2020, as outlined in the NES. Is this a possibility? The aim of this paper, therefore, is to review Ghana's electrification plans and policies to date, examine the challenges that confront electricity access extension, and recommend ways to reach universal access.

\section{METHODOLOGY}

The methods adopted in preparing this paper is a review of the key documents from the Ministry of Power and Ministry of Petroleum (with the two formerly operating together as the Ministry of Energy) and other sector agencies such as the Energy Commission, Ghana Statistical Services, Public Utility Regulatory Commission, reports from the planning agencies, and other information available from the utilities, including the Volta River Authority, Ghana Grid Company, Electricity Company of Ghana, Northern Electricity Distribution Company and authors' own experience with the Ghanaian energy sector. These were complimented with published literature on the subject in local and international scientific database.

\section{EVOLUTION OF GHANA'S ELECTRIFICATION POLICY AND ACCESS TARGETS}

Electricity access definitions vary ${ }^{25,26}$ and indeed there is more than one in Ghana alone. Two different forms of electricity access definitions are used in Ghana by recognised state institutions: the Ministry of Power (MoP) and the Ghana Statistical Services (GSS). MoP defines access to electricity in a community as the total population in the community that has been connected to the grid, irrespective of the number of households that have connection. ${ }^{16}$ By this definition, the population in the particular community is counted as having access to electricity because it is assumed that they are within reach of the grid and could connect by signing a connection agreement with the utility whenever they desired and are able to pay the appropriate connection fees. For this reason, even though MoP estimated electricity access in 2010 to be about $72 \%$ (meaning $72 \%$ of Ghana's population lived in communities with access to the grid), GSS pegged household access to electricity in 2010 at $64.2 \%$, according to the population and housing census conducted in the same 
year. ${ }^{27}$ The GSS measures grid electricity access using the number of households that are actually connected to the electricity grid.

Notwithstanding which of the two definitions is used, Ghana's electrification access still rates high relative to many other countries in the sub-region. Important drivers of this stride is results from (i) strong political will and (ii) long-term planning with clear targets. The country has been one of the few sub-Saharan African countries who set up energy planning policies with clear targets, as far back as 1989 , with the ambitious aim to extend electricity access to all communities with population above 500 by $2020 .{ }^{28}$ In addition to the masterplan, other plans / policy documents have since been developed that provide further details with some targets for different sectors of the economy. The two most prominent plans are the Strategic National Energy Plan (SNEP) developed by the Energy Commission ${ }^{29}$, and the Energy for Poverty Reduction Action Plan (EPRAP) developed by the Ministry of Energy. ${ }^{30}$

Whereas the SNEP has strategic targets for both the demand and supply sectors, EPRAP has targets only for the demand sector. SNEP targets are disaggregated into service, commercial, and residential (household), transport, industrial, and agricultural sectors. For the household sector, the SNEP is built around Ghana's original target of universal access by 2020. It goes further to propose a $15 \%$ increase regarding decentralised rural energy in rural electrification by 2015 , expanding to $30 \%$ by 2020. It proposes a solar energy adoption of $1 \%$ for the hospitality industry through the use of solar water heaters, rising to $5 \%$ by 2020 . For the agricultural and fisheries sector, SNEP recommended a $2 \%$ solar energy penetration by 2015 , increasing to $5 \%$ by 2020 . There were also targets for biodiesel, as fuel for fishing and other agricultural activities. Total electricity demand in the SNEP was estimated at $16,300 \mathrm{GWh}$ by 2015 , expected to increase to $22,300 \mathrm{GWh}$ by 2020 . These targets were expected to impose huge demands on existing electricity infrastructure unless additional generation sources are provided to meet the excess demand and to avoid an energy crisis. The SNEP recommended that government facilitates the infusion of Renewable Energy Technologies (RETs) into the country's electricity generation mix in order to meet the projected demands. It also recommended an action-oriented energy efficiency campaign to save energy. Regrettably, the electricity generated in 2014 (i.e. less than 13,000 GWh) and the trend over the past decade (Figure 2) shows that the 2015 SNEP target of $16,300 \mathrm{GWh}$ is not likely to be met, a phenomenon that has come back to haunt the country's economy. As already shown in preceding sections of this paper, Ghana has suffered great economic losses due to unreliable power supply resulting from low generation capacity.

Around the same time that SNEP was prepared, EPRAP was also prepared by the Ministry of Energy. As the name suggests, EPRAP (Energy for Poverty Reduction Action Plan) targeted delivery of energy for poverty reduction in seven key sectors: Household, Health, Education, Water and Sanitation, Small and Medium Enterprises, Agriculture and Communication \& Technology. EPRAP was aimed at facilitating electricity provision to support services in the aforementioned sectors and to increase productive uses, especially in rural communities.

In 2007, the government rolled out the Ghana Energy Access and Development Project (GEDAP). GEDAP is a multi-donor funded project involving the World Bank, International Development Agency (IDA), Global Environment Facility (GEF), African Development Bank (AfDB), Global Partnership on Output-based Aid (GPOBA), Africa Catalytic Growth Fund (ACGF) and the Swiss Agency for 
Development and Cooperation (SECO). The project is intended to improve the operational efficiency of the power distribution system and increase the population's access to electricity to ensure lowcarbon economy in Ghana through the reduction of greenhouse gas emissions. Government's objective under GEDAP is to increase electricity access from $54 \%$ to $75 \%$ by 2015 with the ultimate aim of universal access. The investment needed to extend grid access to all communities with population above 500 by 2020 was estimated at about US\$ 722 million $^{32}$. It is worth pointing out that the Ghana Ministry of Power quotes electricity access rate at over $80 \%$ as of October $2015 .^{33}$ This presupposes that notwithstanding the power supply challenges, extension of the grid has continued at a faster pace that was planned.

In 2010, the Ministry of Energy published an Energy Policy document, with associated Energy Sector Strategy and Development Plan. The Energy Policy document ${ }^{32}$ outlines Government policy direction for the energy sector, especially within the context of the recurring power crisis. The key highlights of the policy document, inter alia, are to:

- Increase electricity generation capacity to $5000 \mathrm{MW}$ by 2015 and ensure universal access to electricity by 2020 , in line with the NES. This is to be achieved through a public-private partnerships (PPP) in the construction of new power plants and ensuring cost recovery.

- Increase the share of renewable energy in the national energy mix

- Promote energy efficiency and thereby reduce wastage in the generation, transmission, distribution and consumption of energy

- Ensure that efficient and competitive but affordable rates are charged for electricity consumption.

The Energy Sector Strategy and Development Plan ${ }^{34}$ is an addendum to the Energy Policy document and outlines the interventions proposed by government to address the proposed policies. Some of the key interventions include:

- Expansion of some existing thermal plants and conversion of simple cycle plants into combine cycle to increase generation capacity

- Development of promising small hydro plants, with capacities below $100 \mathrm{MW}$

- Completion of grid expansion projects and on-going substations

- Upgrading and refurbishment of electricity distribution network to reduce losses

In 2011, the Parliament of Ghana approved a Renewable Energy Act (RE Act) that seeks to increase the share of renewables in the energy sector. Even though it has not been explicitly stated in the RE Law, it has since been pronounced that Ghana would seek to have $10 \%$ of its electricity generation capacity in 2020 from renewable sources, ${ }^{35}$ using two options: a feed-in-tariff scheme, and an RE purchase requirement by the utilities. Currently, feed-in-tariffs have been published and processes leading to the construction of plants have been defined and gazetted by the Energy Commission (Ref 36). Operational procedures for the obligatory purchase requirements are yet to be spelt out. 


\section{CHALLENGES IN ELECTRICITY ACCESS PROVISION}

\section{Regional disparity and Rural-urban dichotomy}

The Ghana Statistical Service (GSS) disaggregates electricity access into national, urban and rural access. As shown in Figure 3, a little above $85 \%$ of urban households in Ghana had access to electricity in 2010 , compared to only $40 \%$ of rural households. The remaining $60 \%$ of rural households rely mostly on kerosene lamps and flashlight as their source of lighting. Apart from the rural-urban dichotomy in electricity access in Ghana, there is also some regional disparity. Ghana is divided into ten regions, but there is some distinction between the northern regions and the southern regions, with the southern regions wealthier than the northern regions. This has reflected in access to electricity. From the summary shown in Figure 4, the Greater Accra region, which hosts the nation's capital, had more than $85 \%$ of households (both urban and rural) with access to electricity in 2010. Other southern regions, such as Ashanti region, Western region and Central region, had on the average, more than $65 \%$ of households with access to electricity. In contrast, the three northernmost regions, Northern region, Upper East region and Upper West region had on the average about $30 \%$ of households with access to electricity. The majority of households in those regions are farmers. According to Ref 27 , about $79 \%$ of households in those three regions are engaged in agricultural activities, compared to a national average $46 \%$ in 2010 . Flashlights and kerosene lamps dominate lighting access in those three regions.

\section{Generation and demand deficit}

As indicated in section 2 of this paper, Ghana's electricity generation had until 1997 relied solely on hydro with a combined capacity of about 1,200 MW. The first thermal plant for electricity generation was commissioned in 1997 when it became apparent that hydro generation alone was not enough to support a growing electricity demand. There are currently eight thermal plants operating in Ghana out of which six are owned and operated by the state-owned Volta River Authority (VRA) and the remaining two owned by Independent Power Producers (IPP). Thermal plants in Ghana run on Light Crude Oil (LCO), Natural Gas and to a limited extent Diesel.

Over the years, there has been insufficient investment in new electricity generation infrastructure and long gestation periods. ${ }^{37}$ Meanwhile, there has been persistent demand for electricity which is growing at a rate of between 10 and $15 \%$ per annum ${ }^{38}$ and therefore outpacing supply. As shown in Figure 5, the electricity demand sector in Ghana is disaggregated into residential, non-residential, industrial and street lighting demand. The industrial sector is the highest consumer of electricity, followed by residential and non-residential sectors. Whereas industrial consumption has fluctuated over the years, residential consumption has seen a constant increase over the period and this is expected to continue into the foreseeable future. ${ }^{39}$ Industrial consumption decreased from $68 \%$ of total consumption in 2000 to $45 \%$ of total consumption in 2013 . Meanwhile the share of residential consumption has increased during the same period, from 23\% in 2000 to 35\% in 2012. The decrease in industrial demand may be explained by the fact that the Volta Aluminum Company (VALCO), an aluminium smelting plant which historically is the largest single industrial consumer of electricity in Ghana, has had to reduce its production in recent years due to the challenges confronting the power sector. Residential consumption is increasing not only because individual household consumption is 
growing due to increased population and urbanisation, but also because more communities are being added to the electricity grid every year as the country seeks full electrification by the target date of 2020.

Clearly electricity supply in Ghana has not kept pace with demand for the product. The Ghana Energy Commission estimates that Ghana requires a capacity addition of about 200MW per annum to catch up with the increasing demand in the medium to long term. ${ }^{23}$ Unfortunately, the level of investment is not matching up. As of 2013, Ghana's peak demand is about $2300 \mathrm{MW}$, occurring between $6 \mathrm{pm}$ and just before midnight. ${ }^{23}$ Installed electricity capacity is far in excess of $2300 \mathrm{MW}$ which should logically be enough to meet demand. The challenge stems from the fact that the generation plants are not operating at full capacity. Table 1 shows installed electricity generation capacity in Ghana at the end of 2014 and the maximum power generation expected from all the plants when operating at full capacity. Current dependable capacity, which stands at over 2600 , is in excess of the $2300 \mathrm{MW}$ peak demand. However, actual power generated has always fallen short of the maximum expected. The maximum power expected from the dependable installed capacity is about $20,000 \mathrm{GWh}$, however, only $62.8 \%$ (below two-thirds) of the total power expected, was generated in 2014. Hydro generation fared better with $73 \%$ of expected generation during the period. There are bigger challenges with thermal generation, where only 50\% was available in 2014 . The low power generation has necessitated a power rationing programme that has been ongoing since 2011. As at December 2015, the power rationing programme has not ceased.

The shortfall in generation is attributable to drought (which result in low water inflows into the hydropower dams) and shortage of LCO and natural gas for thermal generation. The relatively higher generation from hydro, indicates that the problem is a result of poor thermal generation. Of the two main fuels for thermal generation, natural gas is cheaper than LCO, making natural gas the preferred fuel choice. It has been a challenge, however, obtaining natural gas. Natural gas is currently obtained from two sources: the West Africa Gas Pipeline (WAGP) which has proven unreliable, with erratic supply (see Figure 6) and, since the last quarter of 2014, Ghana's own gas processing plant. In 2014, only about $50 \%$ of the contract volume of 45 trillion standard cubic feet of gas (Tscf) was supplied to Ghana by the WAGP. ${ }^{23}$ Some of the generation plants that operate solely on natural gas, such as the Sunon Asogli plant, completely shut down in times of gas shortage, resulting in large electricity generation deficits.

\section{Transmission challenges}

The transmissions network in Ghana is owned and operated by the Ghana Grid Company Limited (GRIDCo), a state-owned sole transmissions system operator in Ghana. Compared to generation and distribution, the transmissions systems network has fared financially better in the last few years. A study by the World Bank (Ref 20) observed that 'GRIDCo is a well-run transmission company, and is the only power utility in Ghana that is currently financially viable'. The study noted, however, that much of the country's high voltage transmission system is aging badly and becoming increasingly unreliable. Close to half of the country's $161 \mathrm{kV}$ transmission infrastructure, which has been operating since the 1960s, is long past its recommended retirement age..$^{20}$ The robustness of the system will also be tested with the expected increase in electricity from renewables. As part of Ghana's Renewable Energy Act, electricity from renewables is to contribute $10 \%$ of total electricity generation by 2020 . Possible challenges include how GRIDCo would manage erratic generation 
plants like solar and wind which are expected to contribute the majority of the $10 \%$, especially in the face of a low generation reserve.

In 2010, GRIDCo conducted a study to assess the reliability of the transmissions system. ${ }^{40}$ According to the study, the main constraints in the transmission system are step-down transformers in the two largest cities in the country which are operated extremely close and often beyond their safe and reliable available transfer capabilities. For this reason, the transmissions system cannot withstand an unplanned single transmission facility outage without load shedding. Such an occurrence would cut off power supply to all connected loads and cause a blackout. Already, a number of total system collapses in the past were partly attributed to transmission system failures. ${ }^{20}$ Another challenge is that during peak load periods, when power flows across the transmission system are heavy, the transmission network experiences large voltage drops which, if unregulated, could cause voltages to dip below a minimum $5 \%$ threshold at many substations. ${ }^{40}$ Even though the transmissions system currently appears to be managing the loads, it is more like a time bomb, waiting to explode!

\section{Poor maintenance of distribution systems}

Ghana's distribution network is wide and covers more than $70 \%$ of communities in the country. ${ }^{41}$ However, electricity supply is not as reliable as the distribution line extends. It appears that efforts to achieve universal access to electricity in Ghana may have been on top of the agenda and maintenance of the existing distribution systems became a distant second. Underinvestment in the distribution network has resulted in obsolete equipment and unreliable power supply, with most parts of the country experiencing unreliable power supply even when there is no power rationing. Unfortunately, there is no data to show the extent to which distribution failures are affecting power outages, compared to how much results from generation challenges.

One of the critical issues with distribution is losses. As shown in Figure 7, distribution losses in Ghana are currently over $23 \%$ with the average for the past decade at $25.3 \%$, i.e. a quarter of electricity purchased for distribution. It can be observed that between 2011 and 2013, more than 2,000 GWh of electricity meant for distribution could not be accounted for. Even though the percentage loss has gradually eroded from $27.3 \%$ in 2000 to the current $23.6 \%$, a lot more could be done to recover these losses. Distribution losses are both technical and commercial. Commercial losses are illegal connections, metering problems, billing and revenue collection challenges. ${ }^{42}$ Tariffs are set using a loss benchmark of $18 \%$, which presupposes that the distribution companies are expected to reduce losses to within $18 \%$ in order to recover costs.

\section{Perceived high cost of electricity}

The distribution companies, and in fact, the generation and transmissions companies often complain of poor tariffs which impacts negatively on their ability to buy fuel for generation and maintain transmissions and distribution systems. On the other hand, consumers have also felt that service provision is poor and not worthy of increases in tariff. Consumers are also of the view that they should not be burdened with increased tariffs, especially in the face of harsh economic conditions and rampant, prolonged loading shedding. There is also a widespread perception, among consumers, of mismanagement within the utilities. Nonetheless, the Public Utilities Regulatory Commission (PURC) has kept increasing electricity tariffs every quarter, with the recent increase announced in December 2015, with details shown in Table 2. Tariff increases in October 2013 were 
exceptionally high and attracted massive public agitation. Residential tariffs were then increased to the tune of $65 \%$ for lifeline consumption of $0-50 \mathrm{kWh}$ per month and $78.9 \%$ for monthly consumptions above $50 \mathrm{kWh}$. The increases were part of efforts towards a full cost recovery of electricity generation and distribution costs to be implemented over a scheduled period using an automatic adjustment formula. The tariff announcement then was met with opposition by labour unions in Ghana which led to government rolling out a mitigation plan by absorbing $25 \%$ of the electricity tariff in order to avoid countrywide protests. The public agitation sharply contrasts a recent study which found that due to the persistency in unreliable power supply, 'Ghanaian households are willing to pay up to $150 \%$ more tariff in order to enjoy stable power supply'. ${ }^{43}$

The 2004 review of the NES revealed that poor communities were unable to pay their electricity bills. ${ }^{15}$ It is thus not surprising that households consuming the least electricity (0-50 kWh) have their costs heavily subsidized by the government. The situation is even gloomier when assessing electricity for productive activities compared to the developed world where a kilowatt-hour cost of electricity for productive activities is less expensive compared with the cost for residential use, the reverse case exists in Ghana and hence putting off prospective businesses that require the use of electricity. Rural enterprises which are expected to revive rural economies from raw materials production to the stage of value addition are beset with the high cost of electricity and thus leading to less remarkable successes in the productive use programme launched by the Ministry of Energy in the past. It becomes a challenge if a rural farmer has to pay more to use electricity for irrigating farm plots than an urban dweller pays to use electricity for lighting.

\section{TOWARDS UNIVERSAL ELECTRIFICATION: KEY ISSUES AND OPTIONS}

\section{Expanding Access in Rural Communities (Reaching the unserved poor)}

As at 2010, the electricity grid in Ghana has reached all urban communities ${ }^{45}$, notwithstanding the reliability challenges. What remains, with regards to extension itself is coverage to rural communities. There is low access to electricity in rural households, largely because several of these households are in communities where the grid hasn't reached and there is no alternative electricity source. Any efforts to achieve universal electrification in Ghana must necessarily address access extension to rural communities.

An analysis by Mensah et al (Ref 16) using historical trends (Figure 8) indicates it may not be feasible to achieve universal access to electrification (i.e. close to 100\% access) in 2020 and that it may rather be achieved towards 2025. Achieving universal electrification would warrant a change in trajectory from the $A B D$ curve onto the $A B C$ curve in Figure 8 and that would mean changing the current road map. One of the principal factors that militate against achieving universal access by 2020 is the difficulty in sending the grid to all rural communities. Also, many of the un-electrified rural communities have population with less than 500 people. There is the likelihood that about $15 \%$ of Ghana's population may still be living in such communities by 2020 . This stands to mean that if government's original NES objectives were to be upheld, i.e., to extend electricity only to settlements above 500 by 2020 , about $15 \%$ of the rural population is likely to remain unconnected by 2020. Whereas it is a generally accepted fact in Ghana that many communities of population below 500 have benefited from strategic positioning (when located on the grid path between two 
large communities) to be granted access, a lot more of these communities are not fortunate enough as they are located far away from the existing grid.

Another analysis by Lighting Africa (Ref 46 ) shows a less optimistic scenario. Whereas urban household electrification in Ghana is expected to approach $95 \%$ by 2020 , rural household access would still hover around 65\% (Figure 9). Indeed, all these analyses point to a possible defeating of the universal electrification by 2020, except of course that government still stands by its definition of community access, in which case it may be possible to extend the grid to all communities with population above 500 by 2020 .

For many rural communities, alternative forms of electricity access, such as solar home systems (offgrid) and mini-grids built from hybrid technologies using RE resources, depending on which resources present best value for money within those communities, would have to be explored. Generally, the choice of electricity technology in the context of rural electrification is influenced by various actors and factors, including prevailing policy and distributors, service companies and financing institutions and household socio-economics. Even though both grid-connected and standalone options have their own advantages and disadvantages, the underlying principle for choice of a particular mode is adopting the least cost technology options and with minimum maintenance requirements as far as possible. ${ }^{47,48}$ If they prove to be the most feasible, solar home systems have the potential to contribute towards achieving universal access to electricity in Ghana.

A study by Kemausuor et al. (Ref 41), however, found that there is a popular lack of interest in offgrid electrification options in smaller/rural communities in Ghana, especially remote areas which are far from grid lines. The reason for such lack of interest mainly stems from their inability to use the 'small' systems provided to power electrical appliances such as TV sets, refrigerators and electric irons, which makes them prefer grid electrification. The use of fridge for small scale home-based economic activities, appear to be a major reason. Indeed, most people who had experienced solar energy use in their communities explained that they enjoyed no other service besides lighting. More so, other communities turn down offers for off-grid electrification options when they observe that adjacent communities are on grid electrification and these cases are reported to the result of campaign promises made by politicians during electioneering years. ${ }^{49,50}$ Ironically, some residents in rural communities are willing to switch to / add off-grid electrification options due to regular grid power outages. They are unable to do so, however, because of the high initial costs of solar PV home systems.

To ensure that rural communities benefit from the electrification programme, electricity access extension must go hand-in-hand with productive uses. Brew-Hammond and Kemausuor (Ref 51) has proposed the coupling of electricity access initiatives in Africa with productive uses of energy, especially in agriculture. For rural communities, this also means the use of innovative and perhaps separate tariffs for agricultural activities, which could then raise their income levels and make it possible for them to pay their residential tariffs.

\section{Increasing Generation Capacity}

Presently, Ghana has transmission and distribution systems that cover every urban community in the country. ${ }^{41}$ This should in principle ease the process of extending distribution systems to rural communities, however, electricity generation deficit presents a challenge to the country in terms of 
power availability even if distribution lines reached all rural communities. Without enough generation capacity and spinning reserves, proceeding further with extension becomes a catastrophe. This is because as new communities are connected, the less power there would for the increasing population to share and this would result in the widening of the load shedding timetable. As seen in previous sections of the paper, the load shedding has already taken a toll on the economic fortunes of the country and it has become urgent now than ever before to increase generation capacity. The Energy Commission (Ref 23) estimates that to eliminate load shedding, Ghana requires a minimum generation of about $17,350 \mathrm{GWh}$ or a generation capacity of $3,500 \mathrm{MW}$ in 2015 . This requirement considers Ghana's economic position as a middle income country, with expected per capita electricity consumption of about $600 \mathrm{kWh}$.

A number of thermal plants are currently under construction which are expected to add extra generation capacity to the existing capacity at the end of 2015 and early 2016. In December 2015, a $250 \mathrm{MW}$ emergency power barge was brought in from Turkey to augment supply and ease the load shedding timetable. Plants that are still under construction / expansion works as of December 2015 include:

- $110 \mathrm{MW}$ capacity steam unit of the TICO Thermal power plant at Aboadze;

- 200 MW Kpone Thermal Power Plant;

- 160-180 MW Sunon-Asogli gas plant 2;

- $25 \mathrm{MW}$ Trojan thermal plant;

- Retrofitting of the Mines Reserve Plant MRP from 40MW to $76 \mathrm{MW}$

Notwithstanding the new power plants under construction, there still remains the challenge of fuel availability to run the power plants. In the past, the high cost of LCO had discouraged its use as generation fuel. Even though the year 2015 has witnessed historically low crude oil prices, the oil market is volatile and future outlook is dependent on several factors, some of which are not too predictable. There have been challenges with the acquisition of natural gas; clearly, the WAGP has become unreliable. The first gas processing plant in the country began operating in the last quarter of 2014. It has a capacity of 150 Million Metric Standard Cubic Feet per day but currently operates at a capacity of about 120 Million Metric Standard Cubic Feet per day. Additional infrastructure is being put in place to increase the country's gas processing capacity. To supplement gas production from the oil fields and the WAGP, the Energy Commission (Ref 23) and indeed other agencies have proposed other technologies for obtaining gas, such as regasification. This could be explored to make gas available for electricity generation at all times and help solve the fuel supply challenges.

The Renewable Energy Act also offers interesting prospects for grid-connected electricity from renewable resources such as solar, wind, biomass and wave energy. The law, together with the published feed-in-tariff, has spurred private sector interest in renewables electricity generation. As of December 2015, The Energy Commission has granted provisional licenses to 76 applicants ${ }^{1}$ who have applied to construct RE electricity plants. Of these, three plants (one each of solar, wind and tidal) have reached the construction phase and are expected to start generation at the end of 2015 and early 2016. The solar plant, of $20 \mathrm{MW}$ capacity, owned by BXC solar power plant near Mankoadze in the Central Region began feeding power into the grid in December 2015 in a test

\footnotetext{
${ }^{1}$ http://energycom.gov.gh/index.php/register-of-licenses
} 
mode. Due to its variable nature, the PURC limit solar plants without storage to just 20MW per plant and a national total of $150 \mathrm{MW}$ in the short to medium term. This is to encourage the use of advanced storage systems and innovative technologies to reduce variability and ensure power reliability. Also, to solve variability challenges, deployment of non-variable renewables, such as biomass technologies and to some extent small hydro, should be encouraged to provide the majority of the mandated $10 \%$ to avoid situations where a lot of variability from solar could destabilise the transmissions system and plunge the country into darkness in the evenings.

Relying on centralised generation and expanding the national grid alone may not be the best cost optimised option to extend access to especially remote rural communities, some of which are island communities on the Volta Lake. Mini-grid solutions should also be considered when considering new generation solutions. These are also important to reduce the high transmission and distribution losses in the system. An analysis by Kemausuor et al (Ref 52), has shown that with regards to cost, a combination of the grid, mini-grids, and off-grid systems may be the best approach to tackle electrification to the remaining un-electrified communities in Ghana, rather than just the grid. Their assessment shows for instance, that it could cost close to 700 million dollars to use a combination of these three technologies, compared to about 890 million dollars required using the grid alone, in a case study of 2,600 un-electrified rural communities in the country. Two pilot mini-grid projects are currently under construction, and this has led to the drafting of a mini-grid regulation for the country. ${ }^{2}$ Operational issues, such as level of tariff and appropriate tariffing models for mini-grids are yet to be agreed, but these projects are expected to provide the experience needed to encourage private sector participation in the mini-grid sector, through a finalisation of the draft regulation.

\section{Reinforcing Transmissions and Distributions Systems Infrastructure}

Increased electricity generation capacity means more power to wheel from generation companies to bulk consumers and distribution companies for onward sale to other consumers. That calls for a reinforcement of both the transmissions and distributions systems infrastructure. Increased transmission losses have been attributed to the transmission of power from southern Ghana to the middle sector and eventually to the northern parts of the country due to the absence of power generation plants in the Northern parts of the country. The long distance transmission translates into significant losses and stability problems for the transmission network.

The PURC sets transmission tariffs using a maximum transmission loss of $3.5 \%$. This means that losses in excess of $4.5 \%$ puts the transmissions systems operator at a clear disadvantage and it in their interest to reduce transmission losses. Among other possible technical measures to be undertaken to reduce transmission losses, the country should explore spreading future power plants across the entire nation, to make it possible for plants to be located close to load centres. Currently, with the exception of the Bui Hydropower plant, all other power plants are located in the southern parts of the country and thermal plants are close to the coast. Meanwhile, the route from these power plants to the northern most parts of the country covers more than $700 \mathrm{~km}$, creating the possibility of high losses within the transmissions system. The Bulk Oil Storage and Transportation Company (BOST) which is responsible for transporting oil and gas resources from the coast to the rest of the country, has initiated plans to extend gas pipelines to the northern parts of the country. ${ }^{53}$

\footnotetext{
${ }^{2}$ Personal communication with Mr Seth Mahu Agbeve, Deputy Director of the Renewable Energy Directorate, Ministry of Power, Ghana.
} 
This should facilitate the provision of gas to make it possible to build 'smaller-scale' power plants in the Northern parts of the country and thereby reduce losses that are associated with the transport of power. Ghana could also take advantage of provisions within the West Africa power Pool to explore inter-regional connectivity that could boost the stability of its transmissions grid.

\section{Other cross-cutting issues: energy efficiency and its role in enhancing access}

Energy efficiency measures would have to be intensified at the generation, transmission, distribution and consumption sectors. The Energy Commission and some development partners have initiated programmes in this regard but a lot more must be done to address energy efficiency issues. During the 2006/2007 power crisis in the country, a campaign was started in which about six million CFLs were distributed nationwide as a demand side management tool to reduce demand for power. This was hailed as a largely successful programme, saving $124 \mathrm{MW}$ of electricity capacity or 33 million dollars a year. The programme, in a slightly different format, is currently being expanded to other high energy consuming appliances. The Energy Commission, with the support of UNDP and the Global Environment Fund, has introduced a refrigerator exchange programme in which old and inefficient refrigerators are exchanged for new energy efficient refrigerators in a rebate scheme ${ }^{3}$. About 50,000 new refrigerators are expected to replace new units, with energy savings in excess of 35 million $\mathrm{kWh}$ per year. A lot more public campaign is needed to intensity energy efficiency campaigns to decrease residential, commercial, and industrial demand for electricity. Another key area that need critical attention is the promotion of energy efficient building structures. The current building regulation does not have strict energy efficiency codes with regards to the use of building materials. Going forward, the building regulation should be amended to reflect current trends in the building industry. Commercial building rating schemes could also be introduced and award schemes instituted for buildings that achieve high ratings, to serve as a motivation to the building industry.

One other area that needs critical attention is the development of proper indicators to measure energy access in the country. The use of grid extension and electricity service connection alone as indicators for access is not enough, especially in the face of several years of unreliable power which has contributed in part to the country's recent economic recession. Tracking progress must go beyond measuring how many communities or households are connected to the grid. Reliability of the supply must be factored into indicators for monitoring access. Indicators developed by agencies such as the IEA and practical action should be studied and adopted or local indicators developed for monitoring access. Examples include the Multidimensional Energy Poverty Index (MEPI), which measures energy deprivation; and the Energy Development Index (EDI) which distinguishes between energy development at the household and community levels and is intended to make clear the role of energy in human development.

\section{Conclusion}

This paper set out to review Ghana's electrification trend, plans and policies to date, examine the challenges that confront electricity access extension, and recommend ways to reach universal electrification. Compared to other countries in sub-Saharan Africa in general, and West Africa in

\footnotetext{
${ }^{3}$ http://www.energycom.gov.gh/energyguide/news.php?news=95
} 
particular, Ghana has fared relatively better in extending the grid and increasing access to electricity. This has generally been aided by a long term road map developed in 1989 and efforts by successive governments to meet the aims of that road map. A number of challenges remain, however, as Ghana continues on this roadmap to achieve universal access to electricity by 2020 . These challenges may frustrate efforts to achieve universal access to electricity. Even though demand for power has been growing over the years, this has met with inadequate investment into power supply infrastructure. There is also a challenge with the acquisition of fuel for power generation, meaning that even those plants that are available are unable to operate at full capacity. Poor tariffs have been blamed for the inability to procure fuel on a regular basis. At the same time, consumers have felt that the poor services provided by the utilities do not warrant high tariffs. Technical and commercial losses are high and translate to about $30 \%$ for both transmission and distribution. There is an over dependence on the central with power plants mostly built in the southernmost parts of the country.

Several plans and policies have been outlined in the past towards addressing these challenges but very little results have been achieved so far. Going forward, a number of recommendations have been proposed in this review. The over dependence on the grid could make electricity access to remaining population expensive, due to the remoteness of some rural and island communities. In addition to extending the grid, sustainable off-grid and mini-grid solutions should also be explored. Off-grid systems with solar photovoltaic generation can have important trade-offs. Utilities may find it difficult and expensive to manage and maintain isolated systems located in remote areas, due to difficult access and poor communication conditions, and complex transportation logistics. These drawbacks, however, must be balanced against the substantially reduced costs that off-grid systems can offer for remote users and the opportunities that arise for SMEs to enter the energy service provision space. Implementers may need to strengthen institutions and education of beneficiaries, perhaps in a manner that highlights the role of off-grid systems in providing smaller amounts of power in the short term, anticipating grid extension in the future as demand rises.

\section{References}

1. Barnes DF. Meeting the Challenge of Rural Electrification. RFF Press, 2007, 313-327.

2. Tully S. The human right to access electricity. Electr J 2006, 19(3):30-39.

3. http://www.mckinsey.com/ /media/mckinsey/dotcom/insights/energy\%20resources\%20materi als/powering\%20africa/brighter_africa_the_growth_potential_of_the_subsaharan_electricity_sector.ashx (accessed December 19 2015).

4. IEA. World Energy Outlook. International Energy Agency, Paris, 2014

5. IEA. World Energy Outlook. International Energy Agency, Paris, 2015

6. Ozturk I, Acaravci A. The long-run and causal analysis of energy, growth, openness and financial development on carbon emissions in Turkey. Energy Economics 2013, 36: 262-267. 
7. Shahbaz M, Khan S, Tahir MI. The dynamic links between energy consumption, economic growth, financial development and trade in China: Fresh evidence from multivariate framework analysis. Energy Economics 2013, 40: 8-21.

8. GEA. Global Energy Assessment - Toward a Sustainable Future. Cambridge University Press, Cambridge, UK and New York, NY, USA and the International Institute for Applied Systems Analysis, Laxenburg, Austria.

9. Bakhoda H, Almassi M, Moharamnejad N, Moghaddasi R, Azkia M. Energy production trend in Iran and its effect on sustainable development. Renewable and Sustainable Energy Reviews 2012, 16(2): 1335-1339.

10. Oyedep SO. On energy for sustainable development in Nigeria. Renewable and Sustainable Energy Reviews 2012, 16(5): 2583-2598.

11. Essah EA. Energy generation and consumption in Ghana. In Laryea, S, Leiringer, R, Hughes, W, ed. Proceedings of the West Africa Built Environment Research. WABER; 2011 391-401

12. Bazilian $\mathrm{M}$, Nussbaumer $\mathrm{P}$, Rogner $\mathrm{H}$, Brew-Hammond $\mathrm{A}$, Foster $\mathrm{V}$, Pachauri $\mathrm{S}$, et al. Energy access scenarios to 2030 for the power sector in sub-Saharan Africa. Utilities Policy 2012, 20: 116.

13. Ganda F, Ngwakwe CC. Problems of Sustainable Energy in sub-Saharan Africa and Possible Solutions. Mediterranean Journal of Social Sciences 2014, 5: 453-463.

14. Belmans R, Driesen J, Smyth M, Nkwetta D, Van Thong, V. Electricity supply, irregularities, and the prospect for solar energy and energy sustainability in Sub-Saharan Africa. Journal of Renewable and Sustainable Energy 2010, 2: 1-16.

15. Amissah-Arthur, J., 2004. Mainstreaming Low Cost Innovations in Electricity Distribution Networks: National Electrification Experiences Ghana: 1985 - 2004. Arthur Energy Advisors, Ghana, Unpublished, 1-10.

16. Mensah GS, Kemausuor F, Brew-Hammond A. Energy access indicators and trends in Ghana. Renewable and Sustainable Energy Reviews 2014, 30, 317-323.

17. Brew-Hammond A. Kemausuor F. Energy Crisis in Ghana: Drought, Technology or Policy? University Press, Kumasi, 2007, 4-5

18. Bekoe EO, Logah FY. The impact of droughts and climate change on electricity generation in Ghana. Environmental Sciences 2013, 1: 13-24.

19. Kwakwa PA. Disaggregated energy consumption and economic growth in Ghana. International Journal of Energy Economics and Policy 2012, 2: 34-40.

20. http://wwwwds.worldbank.org/external/default/WDSContentServer/WDSP/IB/2013/07/22/000442464 201 30722120043/Rendered/PDF/796560WPOP13140Box0377384B00PUBLIC0.pdf (accessed 10 September 2015) 
21. Forkuoh SK, Li Y. Electricity Power Insecurity and SMEs Growth: A Case Study of the Cold Store Operators in the Asafo Market Area of the Kumasi Metro in Ghana. Open Journal of Business and Management 2015, 3: 312-325.

22. Braimah I, Amponsah O. Causes and Effects of Frequent and Unannounced Electricity Blackouts on the Operations of Micro and Small Scale Industries in Kumasi. Journal of Sustainable Development 2012, 5: 17-36.

23. http://energycom.gov.gh/files/Energy\%200utlook\%20for\%20Ghana\%20-\%202015.pdf (Accessed September 19 2015).

24. Otchere-Appiah G, Hagan EB. Decentralized bioenergy generation: An option to extend access to electricity in remote areas and curb perennial power outages in Ghana. International Journal of Development and Sustainability 2013, 2(2): 1513-1522.

25. Brew-Hammond A. Energy access in Africa: Challenges ahead. Energy Policy 2010, 38(5): 2291-2301.

26. Singh $R$, Wang $X$, Reyes J, Ackom EK. Electricity (in) accessibility to the urban poor in developing countries. WIREs Energy Environ, 2015, 4(4): 339-353.

27. http://www.statsghana.gov.gh/docfiles/2010phc/Census2010_Summary_report_of_final_ results.pdf (Accessed August 20 2015)

28. Kemausuor F, Obeng GY, Brew-Hammond A, Duker A. A Review of Trends, Policies and Plans for Increasing Energy Access in Ghana. Renewable and Sustainable Energy Reviews 2011, 15: 5143- 5154.

29. http://energycom.gov.gh/files/snep/MAIN\%20REPORT\%20final\%20PD.pdf (accessed August 24 2015)

30. Ministry of Energy. Energy for Poverty Reduction Action Plan for Ghana. A Targeted Approach to Delivery of Modern Energy Services to the Poor. Ministry of Energy, Ghana, 2006. ISBN: 9988643-64-0

31. Energy Commission. National Energy Statistics 2000-2014. The Ghana Energy Commission, 2015.

32. Ministry of Energy. National Energy Policy. Ghana Ministry of Energy, 2010.

33. http://www.ghanaweb.com/GhanaHomePage/NewsArchive/Ghana-ranks-highest-in-terms-ofaccess-to-electricity-Donkor-390334

34. Ministry of Energy. Energy Sector Strategy and Development Plan. Ghana Ministry of Energy, 2010.

35. Government of Ghana. Ghana Sustainable Energy for All Action Plan. Government of Ghana, 2012.

36. Energy Commission. Licence Manual for Service Providers in the Renewable Energy Industry (Wholesale Electricity Supply Licence). The Energy Commission of Ghana, 2012. 
37. Adom PK, Bekoe W, Akoena KK. Modelling aggregate domestic electricity demand in Ghana: An autoregressive distributed lag bounds cointegration approach. Energy Policy 2012, 42: 530-537.

38. Energy Commission. 2013 Energy (Supply and Demand) Outlook for Ghana. The Energy Commission of Ghana, 2013.

39. Dramani JB, Tewari DD. An Econometric Analysis of Residential Electricity Demand in Ghana. Mediterranean Journal of Social Sciences 2014, 5(16): 209-222.

40. GRIDCo. Ghana wholesale power reliability assessment 2010. Ghana Grid Company, 2010.

41. Kemausuor F, Brew-Hammond A, Obeng GY, Duker A, Annor FO, Boamah F. GIS-Based Support for Implementing Policies and Plans to Increase Access to Energy Services in Ghana. The European Union Energy Initiative - Partnership Dialogue Facility (EUEI-PDF), 2012.

42. http://www.imanighana.com/2014/01/pricing-and-deregulation-of-the-energy-sector-in-ghanachallenges-prospects/ (Accessed September 20 2015).

43. Twerefou DK. Willingness to Pay for Improved Electricity Supply in Ghana. Modern Economy 2014, 5: 489-498.

44. http://www.purc.com.gh/purc/sites/default/files/electricity and water tariffs for july septem ber 2015.pdf

45. Ministry of Energy. National Electrification Scheme (NES) Master Plan Review (2011-2020). Ministry of Energy, Ghana, 2010.

46. https://www.lightingafrica.org/wp.../25 Ghana-FINAL-August-2012.pdf

47. Palit D, Chaurey A. Off-grid rural electrification experiences from South Asia: Status and best practices. Energy for Sustainable Development 2011, 15: 266-276.

48. Reddy BS, Srinivas T. Energy use in Indian household sector - an actor oriented approach. Energy 2009, 34: 992-1002.

49. Bawakyillenuo S. Policy and institutional failures: Photovoltaic solar household system (PV/SHS) dissemination in Ghana. Energy and Environment 2009, 20(6): 927-947.

50. Bawakyillenuo S. Deconstructing the dichotomies of solar photovoltaic (PV) dissemination trajectories in Ghana, Kenya and Zimbabwe from the 1960s to 2007. Energy Policy 2012, 49: 410421.

51. Brew-Hammond A, Kemausuor F. Energy for All in Africa - To be or not to be?! Current Opinion in Environmental Sustainability 2009, 1:83-88.

52. Kemausuor F, Adkins E, Adu-Poku I, Brew-Hammond A, Modi V. Electrification planning using Network Planner tool: The case of Ghana. Energy for Sustainable Development 2014, 19(1): 92101.

53. http://www.energymin.gov.gh/?p=4078 
Figure captions

Figure 1: Electrification rates and populations without electricity in Africa. Source: Ref 4

Figure 2: Total installed electricity generation capacity and electricity generated (2000-2014). Data source: Ref 31

Figure 3: Main source of fuel for lighting, 2010. Data source: Ref 27

Figure 4: Regional penetration of fuels for light in 2010. Data source: Ref 27

Figure 5: Electricity consumption by customer class. Data source: Ref 31

Figure 6: WAGP gas supply for Ghana in 2013 and 2014. Data source: Ref 23

Figure 7: Trend in distribution losses

Figure 8: Electricity access trends and projected target. Source: Modified from Ref 16

Figure 9: projected electricity access growth in Ghana. Source: Ref 46 
Tables

Table 1: Electricity generation capacity and annual generation

\begin{tabular}{|c|c|c|c|c|c|}
\hline Generation plant & Fuel type & $\begin{array}{l}\text { Installed } \\
\text { capacity } \\
(\mathrm{MW})^{\wedge}\end{array}$ & $\begin{array}{l}\text { Dependable } \\
\text { capacity } \\
(\mathrm{MW})^{\wedge}\end{array}$ & $\begin{array}{l}\text { Expected } \\
\text { maximum annual } \\
\text { generation } \\
(\text { GWh) })^{\prime}\end{array}$ & $\begin{array}{l}\text { Annual } \\
\text { generation, } \\
2014 \text { (GWh) }\end{array}$ \\
\hline Akosombo & Water & 1,020 & 900 & 7490 & 6509 \\
\hline Kpong & Water & 160 & 140 & 1165 & 1148 \\
\hline Bui & Water & 400 & 342 & 2846 & 730 \\
\hline Renewables & Solar & 2.5 & 1.9 & & 4 \\
\hline Total non-thermal & & & & 11501 & 8391 \\
\hline TAPCO & LCO/gas & 378 & 300 & 2391 & 890 \\
\hline $\mathrm{TICO}$ & LCO/gas & 252 & 200 & 1594 & 712 \\
\hline TT1 & LCO/gas & 126 & 110 & 877 & 697 \\
\hline TT2 & Gas & 49.5 & 45 & 359 & 223 \\
\hline Takoradi T3 & $\mathrm{LCO}$ & 132 & 120 & 957 & 87 \\
\hline Sunon Asogli & Gas & 220 & 180 & 1435 & 1255 \\
\hline Mines Reserve & Diesel/gas & 85 & 80 & 638 & 195 \\
\hline Cenit Energy & LCO/gas & 126 & 110 & 877 & 513 \\
\hline Total thermal & & & & 9127 & 4572 \\
\hline $\begin{array}{l}\text { Total (thermal + } \\
\text { hydro) }\end{array}$ & & & & 20,628 & 12,963 \\
\hline
\end{tabular}

^Data from Ref 31; "Expected maximum generation based on dependable capacity

Table 2: Approved residential and non-residential end user electricity tariff effective December 1, 2015*

\begin{tabular}{|l|r|r|}
\hline Residential & Tariff (GHp/kWh) & \multicolumn{1}{|c|}{ Tariff (US\$ cents equivalent) } \\
\hline $0-50$ & 21.0795 & 5.5591 \\
\hline $51-300$ & 42.2910 & 11.1530 \\
\hline $301-600$ & 54.8855 & 14.4744 \\
\hline $601+$ & 60.9839 & 16.0827 \\
\hline Service charge (GHp/month) & 397.7209 & 104.8870 \\
\hline & & \\
\hline Non-residential & & 16.0337 \\
\hline $0-300$ & 60.7983 & 17.0616 \\
\hline $301-600$ & 64.6959 & 26.9210 \\
\hline $600+$ & 102.0817 & 174.8116 \\
\hline Service charge (GHp/month) & 662.8682 & \\
\hline
\end{tabular}

Exchange rates were obtained from the Bank of Ghana for December 14, 2015.

Source: Ref 44 